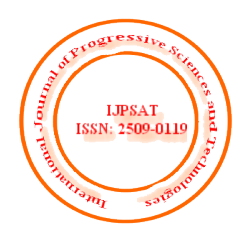

\title{
The Influence of School Literacy Movement and Reading Habit on Student's Achievement
}

\author{
Sri Hayu Wibayanti ${ }^{1}$, Bukman Lian $^{2}$, Mulyadi $^{3}$ \\ ${ }^{1}$ SD Negeri 14 Selat Penuguan, \\ ${ }^{2,3}$ Universitas PGRI Palembang
}

\section{(cc) EY}

\begin{abstract}
This study aimed at determining whether there is an influence of the school literacy movement and reading habit on the student's learning achievement of SD Negeri 31 Pulau Rimau. The sample of this research is fifth grade of 50 students. The data were collected using questionnaire, interviews and documentation. Data were analyzed using the SPSS program. The results showed 1) there was a significant influence of school literacy movement on student's achievement; 2) there is a significant influence of reading habit on student's learning achievement; and 3) there is a significant influence of the school literacy movement and the reading habit together on the student's learning achievement.
\end{abstract}

Keywords - School Literacy Movement, Reading Habit, Student Learning Achievement.

\section{INTRODUCTION}

Reading is one of the most important efforts in the teaching and learning process. Reading is one step that really determines the success or failure of the expected learning process. By reading, we translate; interpret signs or symbols in the language understood by the reader. The concept of education adopted in our country is the concept of lifelong education (Suyatno, 2014). This is in line with what was delivered by Aunurrahman (2012) that with the obligation of every human being to always learn from birth to the end of his life. An advanced society can be supported by a reading culture. All knowledge obtained is not possible without reading, therefore reading culture needs to be developed early. Reading skills play an important role in life because knowledge is obtained through reading. Therefore, these skills must be mastered by students well from an early age to familiarize reading culture.

Reading is a language skill and an important factor in the learning process, because by reading students can obtain information. Reading is one of the activities in literature (Novetli et al, 2019). Literacy cannot be separated from the world of education. Literacy is a means for students to recognize, understand, and apply the knowledge they get in school (Wijayanto, 2018). Furthermore, based on data obtained from the Central Statistics Agency the literacy rate for population aged 15-19 years in 2010 had $99.56 \%$, in 2011, had 98.61\%, in 2012 had $98.85 \%$, in 2013 had $99.42 \%$, and 2014 had 99.67\%. This achievement actually shows that Indonesia has a high literacy rate. However, the challenge currently faced is still low interest in reading. When compared to the results of research conducted by the OECD, Indonesia always ranks lowest. In 2015, Indonesia was ranked eighth in Vietnam, and Thailand ranked $54^{\text {th }}$. This has become a serious problem for the Indonesian people in terms of reading in particular, because reading is the basis for gaining knowledge, skills and forming students' attitudes (Widyastuti, 2017).

School literacy should be given early on to children in elementary schools, so that the habit of student's reading are 
accustomed to reading activities because reading skills play an important role in student's lives because knowledge is obtained through reading (Nopilda and Kristiawan, 2018). All people are required to have high reading power, because all sources of information are obtained through reading. Newspapers, magazines, journals, mostly are presented in text form. Reading skills are closely related to the concept of literacy. Literacy is an initial concept of reading. Basic literacy is related to one's reading ability, but this ability will not be meaningful if it does not intersect with a particular context or culture (Abidin, 2016).

Literacy is not only reading and writing activities, but also the ability to obtain information from what is read and summarizes it. This literacy is applied to schools with the aim students can better master the knowledge that has been read. Literacy is an activity to further cultivate the movement of reading and writing. Literacy has many advantages that can train yourself to be more accustomed to reading and can also familiarize someone whose main thing is a student to absorb information that is read and summarized with the language in which it is understood. The literacy movement was developed by the Ministry of Education and Culture, so that there are now several schools in Indonesia that apply literacy to their students (Widyastuti, 2017). In general, learning provided by teachers in schools is less varied, so the learning process becomes monotonous. This can be seen directly in the learning process at school. It would be nice, if the teacher gives learning material followed by jokes and jest but does not come out of the material provided, so students are not bored and bored when receiving the subject matter provided (Ahmadi, 2012).

The school literacy movement is still considered new to educate students, for researchers who have taught at SD Negeri 31 Pulau Rimau that as long as researchers teach especially in class $\mathrm{V}$, student reading habits are still considered low. This is a material for reflection for researchers to examine more deeply, what factors cause students to be less interested in reading. Are the reading materials considered less attractive? Or the presentation of the reading is considered just the same, so that at first glance the students just need to see and read the title and no longer continue the reading.

After the researcher studies, it turns out that the cause of student's lack of interest in getting used to reading is due to several factors, 1) the reading dish is less interesting; 2) reading does not contain elements of the story; 3) the available book offerings are less varied as the usual picture display. Armed with this study, researchers sought to assist students in developing reading habits so that the learning process provided could arouse student learning and at the end of the teaching-learning process, it could improve student's learning achievement at SD Negeri 31 Pulau Rimau.

Literacy is the ability to read and write (Cristianti, 2013). In the current context, literacy has a very broad meaning. Literacy can mean technological, political, critical thinking, and sensitive to the environment. Sumardoyo (2011) defines literacy as a person's ability to use written or printed information to develop knowledge, thereby bringing benefits to the community (Wandasari et al, 2019). Prasetiono (2012) suggested that the introduction of literacy for early childhood began to be developed. For example in the UK since the 1980s teachers and researchers see it is important to introducing literacy in reading and writing for early childhood. Furthermore Wicaksana (2011) argues that, mastery of language is innate in all early childhood children regardless of culture and religion. This means that from birth until the age of 6 years early children already have the ability in literacy, although they do not learn specifically, but children learn languages through interactions with the environment in which children live.

Based on the description above, it can be concluded that literacy is a set of tangible skills, specifically cognitive skills in reading and writing that are independent of the context in which the intended skills are obtained, from whom these skills are obtained and how to obtain them. Indonesia has indeed succeeded in reducing the number of illiterates. But the next challenge is fostering a culture of reading among Indonesian people. The growth of reading culture is important considering the ability and reading skills are the basis for someone to acquire knowledge, skills, and attitude formation. Being a literate generation means heading for a critical and caring society. That is, critical of all information received, so as not to react emotionally and care about the surrounding environment (Ministry of Education and Culture, 2016).

Indarsih (2018) explained that lately many parties were annoyed by the randomness of people distributing articles without good and bad considerations and also not reading the contents carefully. Instead of sharing true or good information with the public, the opposite is true. Argument wars occur so that it is not uncommon to cause conflict among the people. Low reading interest is one of the causes of the events above. Those who do not culture read and react easily without considering anything are a reflection of the people who do not have information literacy well. To be a person with good information literacy, reading habits are 
needed. If getting used to reading is embedded, the next step is to develop a character who likes to read, and finally has a good reading culture.

Regulation of the Minister of Education and Culture Number 23 of 2015 concerning the Growth of Human Rights Strengthens the efforts to establish such literacy culture. One of the things regulated is the 15-minute activity of reading non-lesson books before the learning time begins. The habit of reading this book is considered to be able to foster interest in reading and improve reading skills so that knowledge can be better mastered. Besides in the form of regulation, government efforts to foster a community of people who love reading are implemented in the form of the School Literacy Movement, Community Literacy Movement and the National Literacy Movement. School Literacy Movement and Community Literacy Movement are conducted in schools for students and other school residents, starting at the elementary level to the secondary school level. While Community Literacy Movement is intended for non-school age communities. School Literacy Movement emphasizes literacy activities that include thinking skills using knowledge sources in print, visual, digital and auditory forms. While Community Literacy Movement still prioritizes reading, writing and arithmetic activities, given the Community Literacy Movement target for non-school literacy communities. To support this literacy culture, the Language Development and Protection Agency, Ministry of Education and Culture, provides reading material for folklore. In 2016, there were 263 books written, consisting of 93 rewrites of folklore and 170 books of new folklore writing.

Literacy is inseparable from the world of education. Literacy will be a means for students to recognize, understand, and apply the knowledge they get in school. Literacy is also related to the lives of students, both at home and in the surrounding environment. The importance of literacy for students makes the Ministry of Education and Culture develop the School Literacy Movement. The goal is that students can become lifelong learners (Indarsih, 2018; Wandasari et al, 2019).

The results of an international survey, Progress in International Reading Literacy Study (PIRLS) in 2011, and the Program for International Student Assessment (PISA) in 2009 and 2012, show that reading skills of Indonesian students are still ranked below. This fact opens our eyes to all that Indonesian student's literacy abilities are still low. Whereas the ability of literacy in the field of information technology today is important so that students understand texts analytically, critically, and reflectively. With good literacy skills, students have the ability to access, understand and use information intelligently and safely. For this reason the School Literacy Movement was developed by targeting the school ecosystem at the level of primary and secondary education. School Literacy Movement is carried out in three stages, starting from growing interest in reading through 15 minutes of reading non-lesson books, increasing literacy through responding to enrichment books, to increasing literacy in all subjects. Literacy growth activities at each level of education are discussed one by one in this edition of the magazine. Some we present in the form of interesting info graphics, so it is expected to be easier to understand.

Based on the Minister of Education and Culture Republic of Indonesia quoted Suhendra (2017) explained that, in general the goal of the school literacy movement is to develop students' character through the culture of the school literacy ecosystem which is manifested in the School Literacy Movement so that they become lifelong learners (Fitria et al, 2019; Kristiawan et al, 2019; Irmayani et al, 2018; Apriana et al, 2019; Tobari et al, 2018; Kristiawan and Tobari, 2017; Lian et al, 2018; Sayer et al, 2017). Specifically, they are 1) developing a culture of literacy in students' reading and writing at school; 2) increase the capacity of residents and the school environment so that literates; 3) making the school a fun and child-friendly learning park so that school residents are able to manage knowledge; 4) Maintaining the sustainability of learning by presenting various reading books and accommodating various reading strategies.

Furthermore Soepandi (2018) states that in formal education; the active role of stakeholders, namely the principal, teachers, educators, and librarians is very influential to facilitate the development of the literacy component of students. In addition, there is also a need for an approach to teaching and learning in which the alignments are clearly focused on the components of this literacy. Opportunities for students exposed to the five components of literacy will determine the readiness of students to interact with visual literacy. As a first step, it can be concluded that a paradigm shift of all stakeholders is needed for the creation of this literacy environment.

Quoted from wikipedia Indonesian reading basic word is the activity of reception, analysis, and interpretation by the reader to obtain the message to be conveyed by the author in writing media. Furthermore Tarigan (2012) states reading is a process that is carried out and used by readers to obtain 
messages, which the writer wishes to convey through the media written language.

In terms of linguistics reading is a process of encoding and discussion of the password, different from speaking and writing which actually involves encoding. An aspect of decoding is linking written words with oral language meanings which include changing the writing print into meaningful sound (Nurgiyantoro, 2012). According to Hamalik (2013) reading is one of the important activities in daily life. Every day we definitely miss a few words or sentences that we have read, whether through announcements, newspapers, magazines or books. Each reading has its own appeal and characteristics so that is what causes and encourages readers to read the reading. One method for gaining knowledge is by reading. According to Ahmadi (2014), there are several factors that influence students' success in achieving learning achievement 1) intelligence factors; 2) talent factors; 3 ) interest and attention factors; 4) motive factors; 5) learning methods; 6) family environment factors; 7) school factors. Furthermore Sardiman (2011) argues that globally the factors that influence student's achievement are divided into three types 1) internal factors; 2) external factors; and 3) learning approach factors. So, student success in achieving good learning outcomes is influenced by various factors. These factors consist of a good level of intelligence, lessons according to the talent possessed; there is a high interest and attention in learning, good motivation in learning, good ways of learning and positive learning strategies developed by teachers. A family atmosphere that encourages children to progress. In addition, an orderly, organized, disciplined school environment is conducive to student competition activities in learning.

\section{METHODS}

The research method is a scientific way to obtain data, rational, empirical and systematic characteristics (Arikunto, 2010). Starting with the study of this research, the researcher sees the elements of related variables leading to quantitative research methods. Sugiyono (2015) argues that quantitative research can be interpreted based on the philosophy of positivism, used to examine populations and specific samples carried out randomly, data collection using research instruments, data analysis is quantitative or statistical in order to test the hypothesis that has been set. According to Sugiyono (2015) that the survey method is used to obtain data on a particular place that is natural, but researchers give treatment in data collection for example by distributing questionnaires, tests, structured interviews and so on. Data analysis techniques about the effect of literacy movements and reading habit on student's achievement in SD Negeri 31 Pulau Rimau used SPSS for Windows Version 21 program. Through input of the results of the data after processing, yields a positive effect on each variable. Data analysis techniques in this study used simple correlation data analysis techniques and multiple regressions by applysing SPSS Windows program. The analysis phase includes 1) descriptive analysis; 2) test requirements analysis; 3) hypothesis testing.

\section{Results AND Discussion}

Description of research data the influence of school literacy movements and reading habits on the learning achievement, especially class VA and VB to multiply read from existing books, especially books in the library. Students are told to obtain literacy from television and print media as well as advertisements. The existence of literacy movements and reading habits can turn out to arouse students' enthusiasm for learning. Evidenced by the results, students are active in following the lessons; students are diligent in asking about existing literacies, both when students watch television and from print media. Curiosity of these students diligently reading, proven student learning outcomes in the learning process the better. This can be seen from the activeness of student learning as shown in the following table.

Table 1. Student's Learning Activity Before Going

Through Literacy Movement and Reading Habits in Class VA

\begin{tabular}{clcc}
\hline No. & Student Involvement in & Total & Percentage \\
& Learning Process & Student & \\
\hline 1 & Actively involved & 11 & 44 \\
2 & Involved Passively & 6 & 24 \\
3 & Not involved & 8 & 32 \\
Number of Students Involved & 25 & 100 \\
\hline
\end{tabular}


Based on the above table, it is known that the involvement of VA class students before being given guidance on the benefits of literacy and reading habits are actively involved 11 students or $44 \%$, in other words literacy activities and reading habits students have an interest in listening seriously subject matter provided, students actively read through literacy that is given properly and correctly with regard to the learning material provided. Students involved passively were 6 or $24 \%$, in other words, the literacy activities of students lack of interest in listening seriously, students passively read the literacy given by the teacher in the learning process and read improvise. While students who are not involved in the learning process are 8 or $32 \%$, in other words, the literacy activities of students are less active, and students just sit and stay quiet, student's literacy activities are absent, and students do not listen to the material delivered by the teacher. Students are not active to ask, read or answer questions from the teacher. Furthermore, the activeness of student learning after being given direction about the benefits of literacy and reading habits can be seen in the following table.

Table 2. Student Learning Activity After Through Literacy Movement and Reading Habits in Class VA

\begin{tabular}{cccc}
\hline No. & Student Involvement in & Total & Percentage \\
& Learning Process & Student & \\
1 & Actively involved & 21 & 84 \\
2 & Involved Passively & 4 & 16 \\
3 & Not involved & 0 & 0 \\
Number of Students Involved & 25 & 100 \\
\hline
\end{tabular}

Based on the above table, it is known that the involvement of VA class students after being directed about the benefits of literacy and reading habits are actively involved 21 students or $84 \%$, in other words literacy activities and reading habits students have an interest in listening seriously subject matter provided, students actively read through literacy that is given properly and correctly with regard to the learning material provided. Students are passively involved 4 or $16 \%$, in other words, student literacy activities lack interest in listening seriously, students passively read literacy given by the teacher in the learning process and read improvise. While students who are not involved in the learning process do not exist. This means that all students are involved in the learning process. As the activeness of students in the learning process both before being given directions about the benefits of literacy and reading habits and after being given directions about the benefits of literacy and reading habits in class VB, can be seen in the following table.

Table 3. Student Learning Activity Before Going

Through Literacy Movement and Reading Habits in Class VB

\begin{tabular}{cccc}
\hline \multirow{2}{*}{ No. } & Student Involvement in & Total & Percentage \\
& Learning Process & Student & \\
\hline 1 & Actively involved & 13 & 52 \\
2 & Involved Passively & 9 & 36 \\
3 & Not involved & 3 & 12 \\
& Number of Students Involved & 25 & 100 \\
\hline
\end{tabular}

Based on the table above, it is known that the involvement of VB grade students before being given guidance on the benefits of literacy and reading habits are actively involved 13 students or $52 \%$, in other words literacy activities and reading habits students have an interest in listening seriously subject matter provided, students actively read through literacy that is given properly and correctly with regard to the learning material provided. Students involved passively 9 students or $36 \%$, in other words, the literacy activities of students lack of interest in listening seriously, students passively read literacy provided by the teacher in the learning process and read improvise. 
While students who are not involved in the learning process are 3 or $12 \%$, in other words, student literacy activities are less active, and students just sit and stay quiet, student literacy activities are absent, and students do not listen to the material delivered by the teacher. Students are not active to ask, read or answer questions from the teacher.
Furthermore, the activeness of student learning after being given direction about the benefits of literacy and reading habits can be seen in the following table.

Table 4. Student Learning Activity After Going

Through Literacy Movement and Reading Habits in Class VB

\begin{tabular}{cccc}
\hline No. & Student Involvement in & Total & Percentage \\
& Student & \\
\hline 1 & Learning Process & 24 & 96 \\
2 & Actively involved & 1 & 4 \\
3 & Involved Passively & 0 & 0 \\
& Not involved & 25 & 100 \\
\hline
\end{tabular}

Based on in the table above, it is known that the involvement of VB grade students after being given guidance about the benefits of literacy and reading habits are actively involved 24 or $96 \%$, in other words literacy activities and reading habits students have an interest in listening seriously subject matter provided, students actively read through literacy that is given properly and correctly with regard to the learning material provided. Students involved passively 1 or $4 \%$, in other words, the literacy activities of students lack of interest in listening seriously, students passively read the literacy given by the teacher in the learning process and read improvise. While students who are not involved in the learning process do not exist, this means that all students are involved in the learning process.

The findings of the research through the distribution of questionnaires given to 50 students at SD Negeri 31 Pulau
Rimau on the influence of school literacy movements and the habit of reading on student's achievement were analyzed using SPSS. As the researcher pointed out in the previous, before the research instrument is distributed to students, the instrument is tested first to find out whether the instrument is valid or invalid and reliable or not reliable. The trial results of the research instruments turned out to be valid and reliable. The test requirements for research data analysis include 1) normality test; 2) homogeneity test; 3) linearity test, as can be seen in the following description.

\section{Normality test}

Data normality test of the effect of school literacy movements and reading habits on the learning achievement of SD 31 Pulau Rimau can be seen in the following table.

Table 5. Normality test

\begin{tabular}{|c|c|c|c|c|}
\hline \multicolumn{5}{|c|}{ One-Sample Kolmogorov-Smirnov Test } \\
\hline & & $\begin{array}{c}\text { School Literacy } \\
\text { Movement }\end{array}$ & Reading Habits & $\begin{array}{c}\text { Student's } \\
\text { Achievement }\end{array}$ \\
\hline & & 50 & 50 & 50 \\
\hline Normal & Mean & 3.3660 & 3.5710 & 3.4050 \\
\hline Parameters $^{\mathrm{a}, \mathrm{b}}$ & Std. Deviation & .38854 & .36367 & .35084 \\
\hline
\end{tabular}




$\begin{array}{lcccc} & \text { Absolute } & .098 & .094 & .118 \\ \begin{array}{lccc}\text { Most Extreme } \\ \text { Differences }\end{array} & \text { Positive } & .098 & .094 & .083 \\ & \text { Negative } & -.075 & -.074 & -.118 \\ \text { Kolmogorov-Smirnov Z } & .692 & .665 & .832 \\ \text { Asymp. Sig. (2-tailed) } & .724 & .769 & .492\end{array}$

a. Test distribution is Normal.

b. Calculated from data.

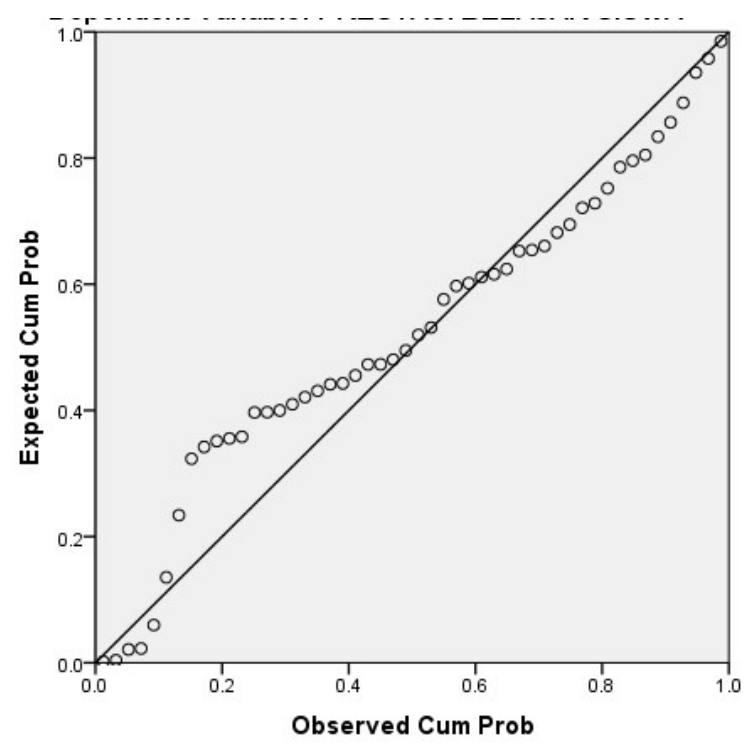

Figure 1. Normal Probability Plot

Based on the table above, it is known that the influence of the school literacy movement on student's achievement is normally distributed. It is known from the results of the analysis obtained a value $0.724>0.05$, and the effect of reading habits on student's achievement is also normally distributed. It is known from the results of the analysis obtained a value $0.769>0.05$. Thus, the influence between variables in this study together is normally distributed. Furthermore, based on the picture above, it appears that the distribution of data is around the diagonal line and nothing is scattered far from the diagonal line, so that the assumption of normality can be met.

\section{Homogeneity Test}

Table 6. Homogeneity Test

\begin{tabular}{|c|c|c|c|}
\hline \multicolumn{4}{|c|}{ Test Statistics } \\
\hline & $\begin{array}{c}\text { School Literacy } \\
\text { Movement }\end{array}$ & Reading Habits & Student's Achievement \\
\hline Chi-Square & $17.000^{\mathrm{a}}$ & $14.000^{\mathrm{a}}$ & $19.000^{\mathrm{b}}$ \\
\hline Df & 24 & 24 & 22 \\
\hline
\end{tabular}



Asymp. Sig.
.849
.947
.645
a. 25 cells $(100.0 \%)$ have expected frequencies less than 5. The minimum expected cell frequency is 2.0 .
b. 23 cells $(100.0 \%)$ have expected frequencies less than 5 . The minimum expected cell frequency is 2.2 .

Based on the table above, it shows that the results of the distribution of questionnaires the influence of the school literacy movement on student's achievement is known the value obtained $0.849>0.05$, and the effect of reading habit on student's learning achievement obtained a value 0.947> 0.05 . This means that the analysis results obtained are homogeneous.

\section{Linearity Test}

Analysis of linearity test about the effect of school literacy movement and reading habit on student achievement in SD 31 Pulau Rimau, the researchers describe in the table below.

Table 7. Linearity Test X1 Against Y

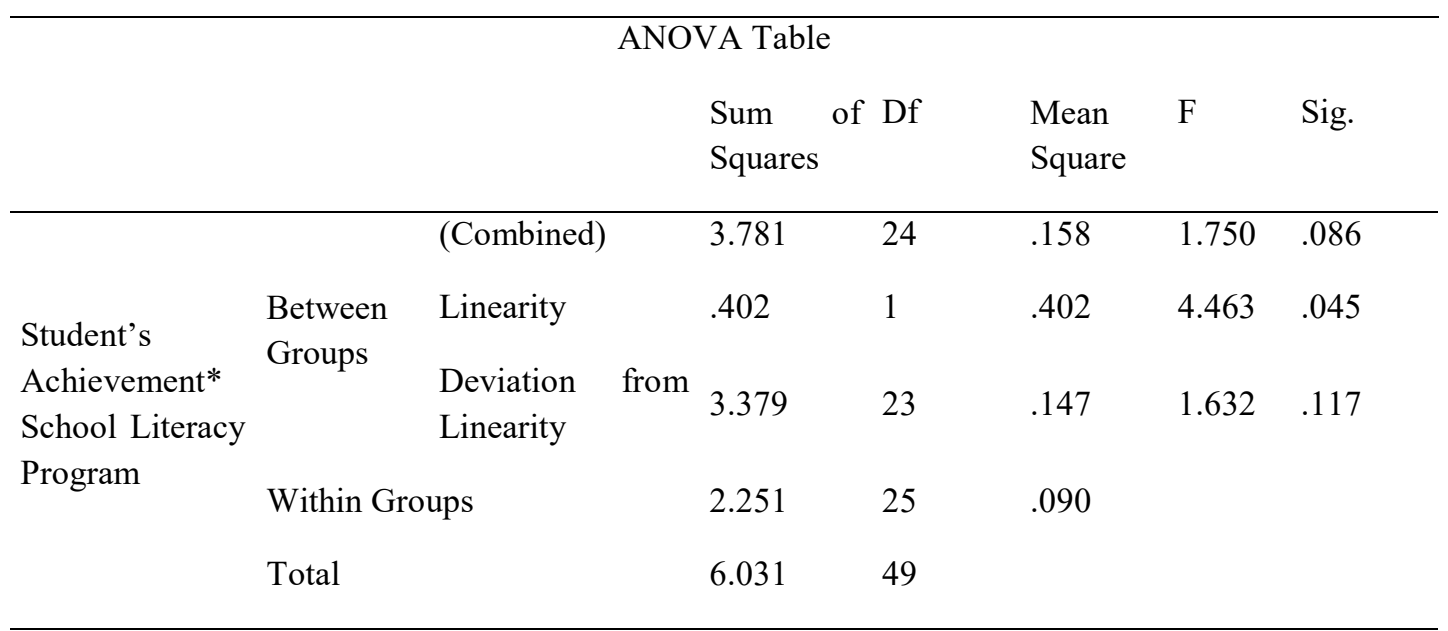

Based on the table above, it shows that F-count $<$ F-table. From linearity test, it shows $0.117<0.005$. Thus the school literacy movement is linear towards student's learning achievement.

Table 8. X2 Linearity Test Against Y

\begin{tabular}{cccccccc}
\hline & \multicolumn{3}{c}{ ANOVA Table } & & & \\
& & Sum of & df & Mean \\
Squares & & F & Sig. \\
& & (Combined) & 3.919 & 24 & .163 & 1.933 & .054 \\
$\begin{array}{c}\text { Student's } \\
\text { Achievement* } \\
\text { Reading Habits }\end{array}$ & $\begin{array}{c}\text { Between } \\
\text { Groups }\end{array}$ & $\begin{array}{c}\text { Linearity } \\
\text { Deviation } \\
\text { from } \\
\text { Linearity }\end{array}$ & 1.282 & 1 & 1.282 & 15.172 & .001 \\
& & 2.637 & 23 & .115 & 1.357 & .228
\end{tabular}




$\begin{array}{cccc}\text { Within Groups } & 2.112 & 25 & .084 \\ \text { Total } & 6.031 & 49 & \end{array}$

Based on the table above, it shows that F-count $<$ Ftable. From linearity test, it shows $0.228<0.005$. Thus the reading habit linearity towards student's learning achievement.

The results of the data analysis were done through the requirements analysis test in three ways 1) normality test, the results obtained showed that the normality test influences the movement of school literacy on student achievement in normal distribution. It is known from the results of the analysis obtained a value of $0.724>0.05$, and the effect of reading habits on student's achievement is also normally distributed. It is known from the results of the analysis obtained value $0.769>0.05$. Thus, the influence between variables in this study together is normally distributed. Furthermore, based on the picture it appears that the distribution of data is around the diagonal line and nothing is scattered far from the diagonal line, so that the assumption of normality can be met; 2) homogeneity test, the results of the distribution of questionnaires the effect of school literacy movement on student's achievement, the value obtained $0.849>0.05$, and the influence of reading habits on student's achievement obtained values $0.947>$ 0.05 . This means that the analysis results obtained are homogeneous; 3) linearity test shows that F-count $<$ F-table. From linearity it shows $0.117<0.005$, and reading habit towards student's achievement shows $0.228<0.005$. Thus the habit of reading habit linearity towards student's achievement.

\section{Analysis of the Coefficient of Determination}

To determine the influence between variables used the coefficient of determination in the analysis using SPSS, as can be seen in the following table.

Table 9. An Analysis of Coefficient Determination

\begin{tabular}{|c|c|c|c|c|c|c|c|}
\hline \multirow[t]{2}{*}{ Model } & \multicolumn{2}{|c|}{$\begin{array}{c}\text { Unstandardized } \\
\text { Coefficients }\end{array}$} & \multirow{2}{*}{$\begin{array}{c}\text { Standardized } \\
\text { Coefficients } \\
\text { Beta }\end{array}$} & \multirow[t]{2}{*}{$\mathrm{t}$} & \multirow[t]{2}{*}{ Sig. } & \multicolumn{2}{|c|}{$\begin{array}{c}\text { Collinearity } \\
\text { Statistics }\end{array}$} \\
\hline & B & $\begin{array}{l}\text { Std. } \\
\text { Error }\end{array}$ & & & & Tolerance & VIF \\
\hline (Constant) & 2.649 & .530 & & 4.996 & .000 & & \\
\hline $\begin{array}{c}\text { School Literacy } \\
\text { Movement }\end{array}$ & .283 & .110 & .313 & 2.569 & .013 & .988 & 1.013 \\
\hline Reading Habits & .478 & .118 & .496 & 4.066 & .000 & .988 & 1.013 \\
\hline
\end{tabular}

Based on the table above, it shows that the coefficient of determination contributed to the influence of the school literacy movement on student's achievement $31.3 \%$, and the contribution of the influence of reading habits on student's learning achievement $49.6 \%$. Thus the hypotheses proposed in this study were 1) there is a significant influence on the school literacy movement on student's achievement is proven true and contributes $31.3 \% ; 2$ ) there is a significant influence of reading habit on student's learning achievement is proven true and contributes $49.9 \%$; and 3 ) there is a significant influence on the school literacy movement and the reading habit together to the student's achievement is proven true.

Based on the results of the study as stated above, that the learning process carried out after being given guidance on the benefits of the school literacy movement and reading habit on the student's achievement of SD 31 Pulau Rimau showed good results. Evidenced by the activity of student learning has increased, both in class VA and VB. The trial questionnaire was conducted in two ways 1) validity test; and 2) reliability test. The results of the validity and 
reliability tests of 20 items questionnaire on each variable showed valid and reliable.

The Ministry of Education and Culture of the Republic of Indonesia appealed that the School Literacy movement aims to familiarize and motivate students want to read and write to foster character. The School Literacy Movement strengthens the character growth movement as outlined in the Minister of Education and Culture Regulation No. 23/2015. The school literacy movement should be given early on to children in elementary schools, so that with the reading habit, students are accustomed to reading because of reading skills plays an important role in the lives of students because knowledge is obtained through reading. All people are required to have high reading power, because all sources of information are obtained through reading. Reading skills are closely related to the concept of literacy. Basic literacy is related to one's reading ability, but this ability will not be meaningful if it does not intersect with a particular context or culture (Abidin, 2016).

Literacy is a means for students to recognize, understand, and apply the knowledge they get in school. Teaching and learning strategies are the whole procedures taken by the teacher and students that allow or provide opportunities for students to carry out learning activities in order to achieve certain goals. What strategy is chosen and used, in essence depends on the ability of the teacher itself which is characterized by the level of knowledge, skills, attitudes and experience and is related to the scope of the teaching-learning process.

Teachers consciously plan their teaching activities systematically by utilizing everything for the benefit of teaching. This means that in the teaching-learning process the process of interaction between the teacher and students must be based on an educational relationship so that teaching and education goals can be achieved (Surakhmad, 2014). Thus, in the teaching-learning process a balance between teacher and student creativity is absolutely necessary. A teacher by increasing his teaching activities means creating and regulating the atmosphere so that students want to learn. The teacher must also master a variety of methods in conveying subject matter and be able to use appropriate methods in the teaching-learning process in accordance with the material to be taught and the abilities of students who receive it, so that the objectives of the teaching-learning process can be achieved effectively, quality and efficiently. Therefore, a good teaching method is a method that can foster the spirit of student learning activities.

\section{Conclusion}

Based on the results of the study, it can be concluded that 1) there is a significant influence on the school literacy movement on student's achievement is proven true and contributes $31.3 \%$; 2) there is a significant influence of reading habit on student's learning achievement is proven true and contributes $49.9 \%$; and 3 ) there is a significant influence on the school literacy movement and the reading habit together to the student's achievement is proven true.

\section{ACKNOWLEDGMENT}

We would like to express our special thanks and gratitude to Rector Universitas PGRI Palembang, Director of Graduate Program and the teachers of Primary School in Selat Penuguan who gave us the support to do this wonderful project. This project was funded independent. Secondly, we would also like to thank our friends in Management of Education who helped us a lot in finalizing this project within the limited time frame.

\section{REFERENCES}

[1] Abidin, Z. (2016). Gerakan Literasi Nasional: Budaya Literasi untuk Tumbuhkan Insan Pembelajar [National Literacy Movement: Literacy Culture to Grow Learners]. Jakarta: Permendikbud RI.

[2] Ahmadi, A., \& Widodo, S. (2014). Psikologi Belajar. Edisi Revisi [Psychology of Learning. Revised Edition]. Jakarta: Rineka Cipta.

[3] Apriana, D., Kristiawan, M., \& Wardiah, D. (2019). Headmaster's Competency In Preparing Vocational School Students For Entrepreneurship. International Journal of Scientific \& Technology Research, 8(8).

[4] Arikunto, S. (2010). Prosedur Penelitian Suatu Pendekatan Praktek [Research Procedure A Practical Approach]. Jakarta: Rineka Cipta.

[5] Aunurrahman. (2012). Belajar dan Pembelajaran [Study and Learning]. Bandung: Alfabeta.

[6] Cristianti. (2013). Pembelajaran Multiliterasi [Multi Literacy Learning]. Bandung: Refika Aditama.

[7] Directorate General of Primary and Secondary Education, Ministry of Education and Culture of the Republic of Indonesia. 2016. The main design of the School Literacy Movement, available from http://dikdas.kemdikbud.go.id/index.php/design-indukgls-kemendikbud/ 
[8] Fitria, H., Kristiawan, M., \& Rasyid, A. (2019). The Educational Character on Instruction. Opción, Año 35, Especial No.21 (2019): 964-979

[9] Hamalik, O. (2013). Proses Belajar Mengajar [Teaching and learning proces]. Jakarta: Bumi Aksara.

[10] Indarsih, S. (2018). Pentingnya Literasi di Era Globalisasi [The Importance of Literacy in the Globalization Era]. Yogyakarta: Universitas Gadjah Mada.

[11] Irmayani, H., Wardiah, D., \& Kristiawan, M. (2018). The Strategy of SD Pusri In Improving Educational Quality. International Journal of Scientific \& Technology Research, 7(7).

[12] Kristiawan, M., \& Tobari. (2017). The Characteristics of the Full Day School Based Elementary School. Transylvanian Review, 1(1).

[13] Kristiawan, M., Nizarani., \& Syamsidar. (2019). Role of School on Forming Character of Z-Generation Through Entrepreneurial Skills. International Journal of Scientific \& Technology Research, 8(10).

[14]Lian, B., Kristiawan, M., \& Fitriya, R. (2018). Giving Creativity Room to Students through the Friendly School's Program. International Journal of Scientific \& Technology Research, 7(7).

[15] Nopilda, L., \& Kristiawan, M. (2018). Gerakan Literasi Sekolah Berbasis Pembelajaran Multiliterasi Sebuah Paradigma Pendidikan Abad Ke-21 [School Literacy Movement Based on Multi Literacy Learning A $21^{\text {st }}$ Century Education Paradigm]. JMKSP (Jurnal Manajemen, Kepemimpinan, dan Supervisi Pendidikan), 3(2).

[16] Novelti., Kristiawan, M., Erpidawati. (2019). Development of the Descriptive Writing Learning Model using the Audio Visual Media. International Journal of Recent Technology and Engineering, Volume-8 Issue-3, September 2019.

[17] Nurgiyantoro, B. (2012). Pengajaran Bahasa dan Sastra Indonesia [Teaching Indonesian Language and Literature]. Yogyakarta: BPFE.

[18] Minister of Education and Culture Regulation Number 23 Year 2015. School Literacy Movement. Jakarta: Ministry of Education and Culture R.I.
[19] Prasetiono, D. (2012). Rahasia Mengajarkan Gemar Membaca Pada Anak Sejak Dini [Secrets of Teaching Reading Fondness to Children Early]. Jogjakarta: Think.

[20] Sardiman, A. M. (2011). Interaksi dan Motivasi Belajar Mengajar [Interaction and Teaching and Learning Motivation]. Jakarta: Raja Graffindo Persada.

[21] Sayer, I. M., Kristiawan, M., \& Agustina, M. (2018). Fairy Tale as a Medium for Children's Character Cooperation Building. Al-Ta lim Journal, 25(2), 108116.

[22] Soepandi. (2018). Supervisi dan Administrasi di Sekolah [Supervision and Administration in Schools]. Jakarta: Raja Graffindo Persada.

[23]Suhendra. (2017). Journals. Cultivating the School Literacy Movement. Jakarta: University of Indonesia.

[24] Sugiyono. (2015). Metode Penelitian Kuantitatif Kualitatif dan R\&D [Qualitative Quantitative Research Methods and R\&D]. Bandung: Alfabeta.

[25] Sumardoyo, S. (2011). Strategi dan Teknik Pembelajaran Membaca [Reading Learning Strategies and Techniques]. Yogyakarta: Graha Ilmu.

[26] Surakhmad, W. (2014). Motivasi dan Interaksi Belajar-Mengajar [Motivation and Teaching-Learning Interactions]. Bandung: Tarsito.

[27] Suyatno. (2014). Teknik Pembelajaran Bahasa dan Sastra [Language and Literature Learning Techniques]. Surabaya: SIC.

[28] Tarigan, H. G. (2012). Menulis Sebagai Suatu Keterampilan Berbahasa [Writing as a language skill]. Bandung: Angkasa.

[29] Tobari., Kristiawan, M., \& Asvio, N. (2018). The Strategy of Headmaster on Upgrading Educational Quality In Asean Economic Community (AEC) Era. International Journal of Scientific \& Technology Research, 7(4).

[30] Wandasari, Y., Kristiawan, M., \& Arafat, Y. (2019). Policy Evaluation of School's Literacy Movement on Improving Discipline of State High School Students. International Journal of Scientific \& Technology Research, 8(4). 
[31] Wicaksana, G. (2011). Buat Anakmu Gila Membaca [Make Your Children Crazy Read]. Jogjakarta: Buku Biru.

[32] Widyastuti. (2017). Fase Pendidikan Anak Usia Dini [Early Childhood Education Phase]. Jakarta: Univertias Terbuka.

[33] Wijayanto, D. (2018). Dasar-Dasar Keterampilan Membaca dan Menulis [Basics of Reading and Writing Skills]. Bandung: Angkasa. 